\title{
Investigating the Relationship between Individuals' Attitudes and Marketing Knowledge Sharing
}

\author{
Mohamad Reza Hamidizadeh ${ }^{1} \&$ Parinaz Aghaei Meibodi ${ }^{2}$ \\ ${ }^{1}$ Management and Accounting Faculty, Shahid Beheshti University, Tehran, Iran \\ ${ }^{2}$ Department of Business Management, Shahid Beheshti University, Tehran, Iran \\ Correspondence: Mohamad Reza Hamidizadeh, Management and Accounting Faculty, Shahid Beheshti \\ University, Tehran, Iran. E-mail: m-hamidizadeh@sbu.ac.ir
}

Received: October 8, 2016

Accepted: October 21, 2016

Online Published: January 5, 2017

doi:10.5539/res.v9n1p106

URL: http://dx.doi.org/10.5539/res.v9n1p106

\begin{abstract}
The aim of this study is to investigate the relationship between individuals' attitudes and marketing knowledge sharing. This research is an applied objective research and data collection method of description-correlation nature the subjects under study by this research are employees of Arak Shaz and petrochemical industry. The sample size was estimated 90 people. The method is stratified random sampling. A standard questionnaire was used to collect data. Marketing knowledge sharing questionnaire of Moghimi and Ramazani (2011) contains 17 items and attitudes questionnaire of Hamidizadeh (2010) contains 5 items. Logical validity (face and content) of questionnaires was reviewed and approved through university professors and several experts of this industry. Also construct validity was reviewed and approved by confirmatory factor analysis using AMOS software. Cronbach's alpha coefficient of 7.0 was obtained for variables that indicate internal consistency of items and acceptable reliability of the questionnaire. The research hypothesis test using univariate linear regression was performed with application of software SPSS. The results showed that, given that the t-statistic value is less than -1.96 $(\mathrm{t}=-2.39)$, the relationship between two variables, attitudes and marketing knowledge sharing was significant at the $5 \%$ error level $(\mathrm{P}-\mathrm{Value}<0.05)$. So, the relationship between marketing knowledge sharing and attitudes is positive and direct. This means that people in the organization do not have positive tendency and attitude to share their knowledge with others and negative attitudes regarding the sharing of knowledge has had more impact on staff. Standard regression coefficient $(0.15)$ also specified the share of independent variable in explaining the changes of dependent variable so that for every one unit increase in negative attitude of individuals, knowledge sharing decreases 0.15 percent.
\end{abstract}

Keywords: individuals' attitudes, knowledge, marketing knowledge sharing, petrochemical industry

\section{Introduction}

The central core of businesses in the future will be their capabilities in knowledge management. Knowledge will be one of the most pivotal parts of competitive advantage of every business (Chang \& Lee, 2008). The most important type of intellectual capital of the organization is knowledge that is the first strategic source of learning organizations in the current era.

Nonaka (1995) research revealed how organizational knowledge is created, transmitted, shared and forwared to other organizations. However, many scientists rejected work of Nonaka in connection with the conversion of tacit knowledge. His works established a series of universal terms that are used to describe the theory of creating and turning knowledge. Scientists often divide knowledge into two types, tacit and explicit. Tacit knowledge is often known as difficult or embedded knowledge in fact it is a kind of knowledge that cannot be expressed in the form of word, number, sentence and the like. Tacit knowledge is deeply hidden in personal actions and experiences. Explicit knowledge that is often called sparse knowledge, is a knowledge that can be documented and passed on to others. Yet these two types of knowledge are dissociated by their properties. Explicit knowledge without tacit knowledge loses its meaning quickly (Kumar, 1992).

According to Davenport and Pruska, knowledge is a fluid mix of experiences, values, information related to specific evidence and approaches that provides a framework for evaluation and combination of new experiences and information. They also argue that in an organization, not only knowledge is in documents but also in 
organizational routines, processes, practices and norms (Hamidizadeh, 2010). Malhotra says that knowledge in the minds of members of the organization is considered a rich source for the organization. He defines knowledge management as a synergic combination of the data conversion process and the human creative and innovative capacity (Malhotra, 2003). Rastju considered knowledge management as a system and process of mobilizing the coordination of organization in relation to the acquisition activities, creation, storage, dissemination, development and the spread of knowledge by individuals and groups in the pursuit of organizational goals (Carter \& Skarburgh, 2001).

Sai and Shin claimed that management of marketing knowledge involves the formation, dissemination and storage of marketing knowledge. Marketing knowledge dissemination is equal to concept of sharing marketing knowledge, for marketing knowledge dissemination describes the process to share knowledge from various sources as well as exciting new knowledge or even understanding it (Shin \& Sai, 2004). Glizer believes that marketing knowledge is strategic asset of the organization. This knowledge is the trick required to perform marketing activities. Marketing knowledge includes research, administrative channels, promotion, product design and marketing information system and other items (Glizer, 1991). Although there are many conceptual and empirical studies in the field of knowledge sharing in management literature, little information is available about marketing knowledge sharing. Sebra and his colleagues understood that many factors have been found to be effective marketing knowledge sharing, including personal factors (self-efficacy, organizational commitment, consistency, awareness and risk taking (experience), environmental factors (available supports, major and minor rewards and employment powers) and systemic factors (accessibility and quality) (Sebra et al., 2005). Considering the importance of the subject, this paper is seeking to investigate the relationship between people's attitudes and marketing knowledge sharing.

\section{Theoretical Foundations}

\subsection{Building Blocks of Marketing Knowledge}

According to Rossiter, there are four aspects of marketing knowledge: marketing concepts, structural frameworks, strategic principles and research principles. There is no clear definition different of shapes and values for marketing knowledge. To define marketing knowledge, we must go back to the definition of marketing. The main purpose of marketing is customer satisfaction in profitability. Marketing is the effort to discover the needs and demands of customers, strategies and techniques of competitors at the same time as well as emphasizing the need for customer and competitors' identification (Rossiter, 2001). In Table 1, you'll see a different display of elements of marketing knowledge.

Table 1. Summary of building blocks of marketing knowledge

\begin{tabular}{lc}
\hline \multicolumn{1}{c}{ Building blocks of Marketing knowledge } & Sources \\
\hline $\begin{array}{l}\text { Organized and structured information about markets-customers competitors-trends } \\
\text { Customer knowledge (retail), consumer knowledge (market research) Market knowledge } \\
\text { (third party information providers) }\end{array}$ & $\begin{array}{c}\text { Tsai and Shin (2004) } \\
\text { Shaw, Subramaniam Tan } \\
\text { and Welge (2001) }\end{array}$ \\
$\begin{array}{l}\text { Knowledge of factors, control of factors and the use of knowledge in new markets } \\
\text { Product Development Management (PDM) Supply Chain Management (SCM) Customer }\end{array}$ & Sirvastava (2010) \\
$\begin{array}{l}\text { Relationship Management (CRM) } \\
\text { Customer knowledge process-research marketing and development of relation-knowledge } \\
\text { of competitors }\end{array}$ & Li and Calantone (2006) \\
Knowledge about customers, competitors and market & Deshpande (2001) \\
\hline
\end{tabular}

\subsection{Factors Affecting Marketing Knowledge Sharing}

Some of the factors affecting marketing knowledge sharing are as follows.

\subsubsection{Self-Efficacy}

Self-efficacy was invented by Bandura. He defined self-efficacy as that people judge about their abilities to organize and execute practical courses required for achieving a specified performance but this subject do not point that what abilities a person has rather it is about the differences that you might expect from a person about what can he do with whatever skills that he has. Self-efficacy is trying to measure the individual concepts around doing 
special tasks. On the other hand, self-efficacy is a subjective concept but, not a physical and real one (Bandura, 1986, p. 391).

Stakovich and colleagues conducted an analysis and found that there is a direct and positive correlation between self-efficacy and organizational variables (Stakovish et al., 1998). Davis believes that self-efficacy is measure of person's ability to perform certain tasks before he starts to work. Self-efficacy has a very close relationship with easy to use these two factors employed in technology acceptance model.

Easy to use concept refers to the degree of confidence of each individual, using a special system that does not require any effort. The following description is one of the definitions of facilities: free from any hardship or hard effort (Soltani, 2013).

Davis believes that balance and easy to understand and easy to use a program compared to other program is more acceptable to the consumer. Belief in facility and ease to use and usefulness are direct assumptions and our target. However, Davis and Cabra spoke about the effect of the extent of self-efficacy role in knowledge sharing and also confidence of each individual about degree of marketing knowledge sharing with others (Davis, 1996; Kabra, 2006). Kalman showed that self-efficacy affects knowledge sharing. Self-efficacy of marketing knowledge sharing affects real sharing of knowledge and its specific interests and tendencies of knowledge sharing; we expect to have a negative effect, self-efficacy of marketing knowledge sharing on the dangers perceived of knowledge sharing (Kalman, 1999).

\subsubsection{Economic Resources}

Economic resources are favorable outcomes of a certain performance before doing it. Employees before marketing knowledge sharing analyse future interest and then decide whether or not to share their marketing knowledge. This particular interests can influence employees' purposes for their marketing knowledge sharing with each other, the interests affect the tendency of employees to share marketing knowledge. These interests are divided into two parts: economic interests and social interests. Kalman classified these interests into three major groups that these categories intensify clear thoughts used for social activities: these three categories include economics-social psychology and sociology (Anderson, 2006).

1) Economic interests are a series of direct and indirect monetary and financial interests like high salary, monetary rewards, high rank and positions in the organization a chart, etc.

2) Social interests are those derived essentially from human feelings and emotions such as, more friends, social respect status.

3) Greater knowledge sharing occurs when the employee's benefits are achived in such a way that their motivation is higher than the costs according to the theory of hope, intent to perform a certain task in a unit, clearly depends on the outcome of that task. Positive outcomes that people understand are related to the works done and tendency of most people to do these works that create positive outcomes.

Cabra and colleagues demonstrated that rewards have an average and direct on effect knowledge sharing. When the decision-makers have a clear understanding of the total benefit of an organization from knowledge-sharing, they encourage the culture of knowledge sharing in an organization. Organizational rewards have a drastic effect on the behavior and performance of employees of an organization (Cabra et al., 2006). Bok and Kim claimed that the expected rewards and expected associations will have a positive impact on tendency toward knowledge sharing (Bok \& Kim, 2002). Specific interests are classified into two classes, economic and social benefits. Economic benefits include financial rewards and job promotions. Social benefits include high recognition, reputation and finding new friends. These benefits have a positive effect on knowledge sharing. We anticipate that specific benefits from knowledge sharing have direct or indirect positive effect on the tendency toward marketing knowledge sharing.

\subsubsection{Risks Discussed}

Knowledge is power and sharing means to share this power. Marketing sharing is a risky task because as Liao and others have pointed out, for people in severe competitive environment, knowledge-sharing means that individual knowledge is transferred to those who are possibly a part of your previous or future competitors. Marketing knowledge sharing is usually for the benefit of the organization, but not for the benefit of employees. Employees are usually cognizant of specific knowledge that have as their ability to stay in the same organizational position (Liao et al., 2003). So their sharing of knowledge seems a dangerous issue. Certain risks are divided into two categories-economic risk and social risk. Economic risk include: the loss of job and the use of knowledge. Social risks, include the loss of friends and jealousy of colleagues, The identified risks have a 
negative impact on knowledge sharing. We expect that the specific risks of marketing knowledge sharing have direct or indirect negative impact on people's tendency toward their marketing knowledge sharing with others.

\subsubsection{Tendencies}

It is believed that the individual tendencies for a specific behavior could be influenced by the individual's purposes to accomplish a task like sharing his knowledge and can have a greater impact on the actual performance of the individual. Ajzan and Fyshbayand said that there are more than 500 different ways to measure tendencies that now this number has increased (Ajzen \& Fyshbayand, 1980). Tendencies show a summary assessment of the psychological cases that exist in different dimensions. The dimensions of tendency include good, bad, loss, profit, loving or not loving. It is clear that there isn't a general consensus about definition of and how to measure tendencies. Tendency to knowledge sharing depends on positive feeling of person to his knowledge sharing (Ajzen \& Fyshbayand, 2000). Cook and Gaeo understood that the tendency to knowledge sharing is a function of strong channels, attractive capacities and external those stimuli are not influenced by motivation (Cook \& Gaeo, 2005). Kanra, Bak and Kim raised that positive attitude toward knowledge sharing has a positive relationship with comparing knowledge sharing and consequently good behavior of knowledge sharing (Bok \& Kim, 2003).

\subsection{The Empirical Background of Research}

Keshavarzi and colleagues in have conducted a research 2012 entitled the role of interpersonal trust with knowledge sharing within the organization that the case study of research is the headquarters of the National Iranian Gas Company. They believe that trust through cooperation and solidarity between members of group causes developing and promoting the spirit of the group and directly or indirectly affect the efficiency of the group and ultimately the performance of the organization. Knowledge sharing in organizations leads to faster individual and organizational learning, increasing creativity and improving individual and organizational performance. So organizations strengthen knowledge sharing and encourage their employees to it. Confidence in the organization and understanding its relationship with knowledge sharing is important particularly for achieving competitive advantage of organizations. The present study was aimed to "identify the role of interpersonal trust with knowledge sharing in the headquarters of the National Iranian Gas Company". Trust and knowledge sharing data were collected, investigated and analyzed by correlation method. The findings of study confirmed the positive and significant correlation between interpersonal trust with sharing knowledge and their components. The conceptual model that has been used in this study is as follow.

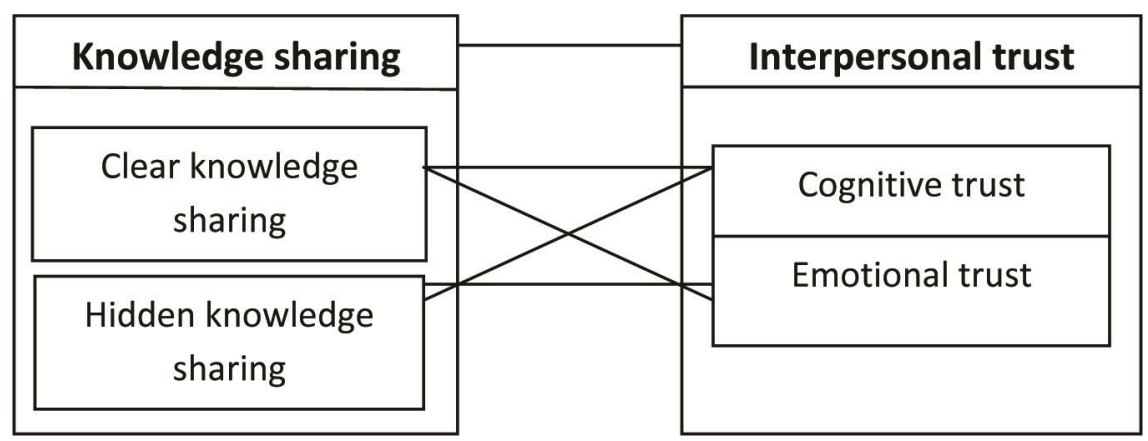

Figure 1. Conceptual model of the role of interpersonal trust with knowledge sharing in organization (Keshavarzi et al., 2012)

Hypothesis test results indicate there is a significant positive relationship between interpersonal trust variable with knowledge sharing variable and components of them. Hamidizadeh and Azizi in 2009 investigated the factors influencing knowledge sharing and impact of knowledge sharing on the organization. The conceptual model that is used in this article is as follows: 


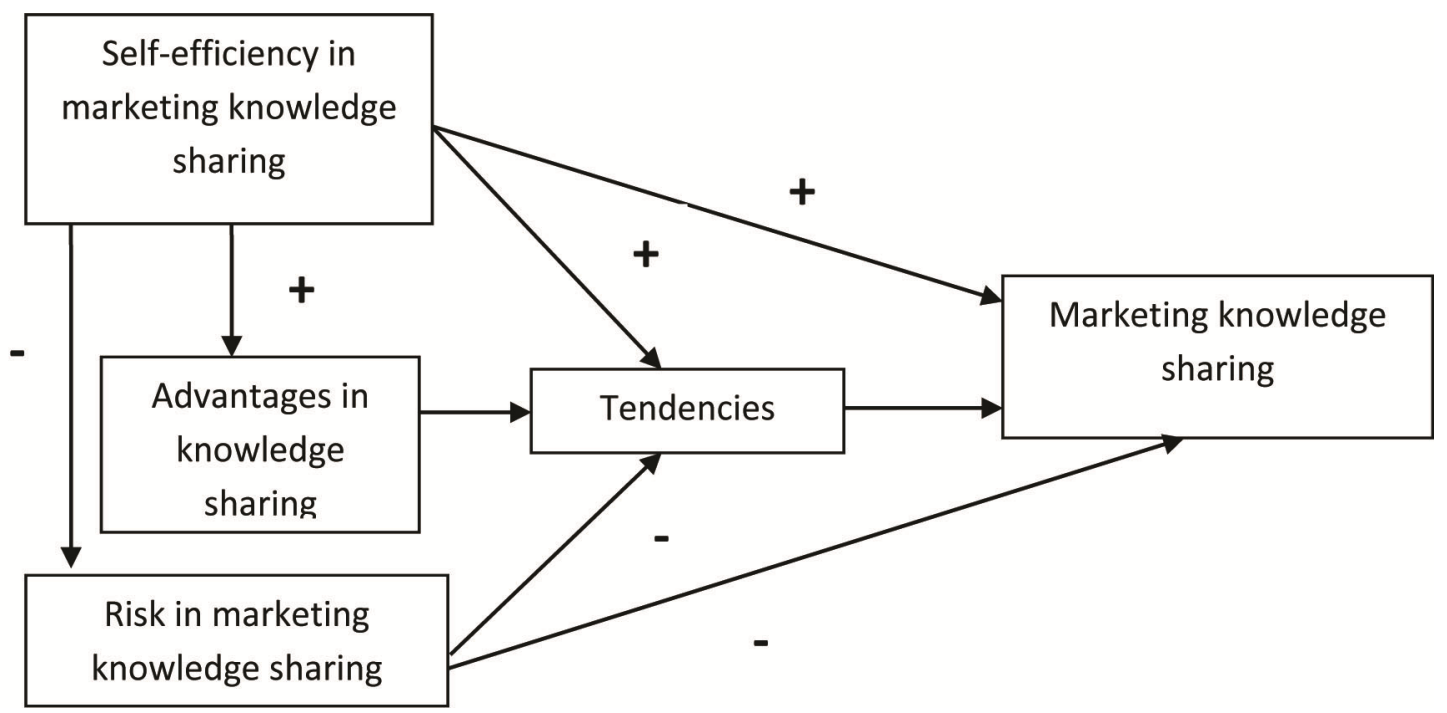

Figure 2. Conceptual model of factors influencing marketing knowledge sharing (Hamidizadeh \& Azizi, 2009)

The experimental findings of this research show a specific vision for the role of meditation of tendencies in marketing knowledge sharing that this role exists between interests and risk with marketing knowledge sharing. The results of SEM support the positive impact of self-efficiency, particular interests and tendencies on marketing knowledge sharing. Findings show that self-efficiency has positive impact on interests and negative impact on risk. This shows that the most impact is for self-efficiency even more than the impact of specific interests on marketing knowledge sharing. Research also shows that risks have negative impact on tendencies of marketing knowledge sharing. Outputs show that there is no direct impact of specific interests and specific risks on marketing knowledge sharing. Impact of specific interests on tendencies is more than specific risks. Specific interests affect marketing knowledge sharing equal to 0.053 while specific risks have an impact equal to -0.148 on the marketing knowledge sharing and this indicates that direct impact of specific interests on marketing knowledge sharing is less than specific risks on marketing knowledge sharing; on the other hand, risk has greater value for employees than interests. In addition, research shows that self-efficiency is the first thing to predict marketing knowledge sharing after that, tendency is placed in the second position, specific risks in the third position and specific interests in last position.

In general, although the assumptions of model have a proper communication with the data collected, but it is better to remove two paths from the primary model to affect the P-level. The modified model shows better balance between the assumptions and the data collected.

The study is a guide for executives in the marketing department to increase marketing knowledge sharing in the organization and among employees. The results show that to encourage marketing knowledge sharing, the most important factor is self-efficiency in marketing knowledge sharing. Managers can strengthen marketing knowledge sharing through methods including enabling the environment for successful marketing knowledge sharing, the introduction of successful employees in marketing knowledge sharing social encouragement of employees in designing reward system that covers both economic and social fields that is a good idea to increase marketing knowledge sharing. Researchers findings show managers that to promote marketing knowledge sharing in marketing the focus should be on decreasing marketing knowledge sharing related to risk taking (economic and social) not on reducing marketing knowledge sharing of interests. On the other hand, the security of employees in marketing knowledge sharing should be ensured.

Rezvan Alian Krabshen in 2007 in a paper titled a model of previous knowledge sharing looks at how the organizations can be skilled and experienced in support of knowledge sharing, by identifying background of knowledge sharing. The basic foundation of this article is that effective knowledge sharing has three interdependent links. The first link is related to namely the value of knowledge held by members of the organization, namely orientation of learning. Here, three organizational values are described, which are normally related to the participation in learning: commitment to learning, open-mindedness shared view, common vision. The second link is related to market orientation which is normally focuses on three areas: customer focus, competitor focus, interfunctional coordination and coordinators. The final link is related to the absorbent 
capacity of organizations that is defined as "the ability to recognize the value of new external information, standardizing it, and applying it to commercial ends". The paper also argues that successful knowledge sharing needs to enable of infrastructure of information technology in the Figure 3, a system of rewards that encourages and strengthens knowledge sharing activities and a positive social interaction that build confidence among members of the organization. The article offers a work in progress. The final version of the proposed model is tested in the Technology Park in Australia and Malaysia. Conceptual model presented in this paper is as follows:

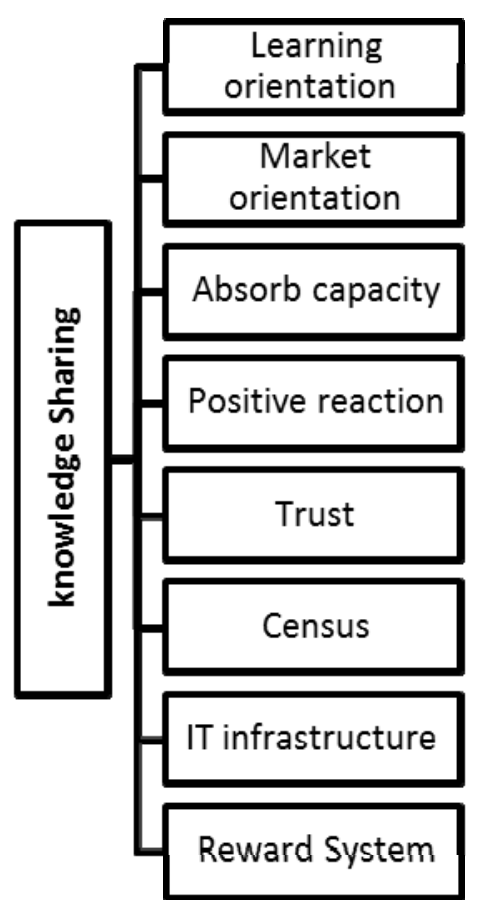

Figure 3. Conceptual model of previous knowledge sharing (Rezvan Alian Krabshen, 2007)

The research takes a look at how organizations can be sophisticated in support of the sharing of knowledge, by identifying records of knowledge sharing. The basic hypothesis of this article is that effective knowledge sharing has three related links. The first link is related to the value of knowledge held by members of the organization, orientation of learning. Here, three organizational values are described, which are normally related to the participation in learning: commitment to learning, open-mindedness shared view. The second link is related to market orientation which normally focuses on three areas: customer focus, competitors focus and interfunctional coordination. The final link is related to the absorbent capacity of organizations that is defined as "the ability to recognize the value of new external information, standardizing it, and applying it to commercial ends". The paper also argues that successful knowledge sharing needs to enablers in the form of infrastructure of information technology, a system of rewards that encourages and strengthens knowledge sharing activities and positive social interaction that build confidence among members of the organization.

These links will be shown in different perspectives of knowledge. For example, while product-based strategy and competition, generally creates markets and customers that is the starting point for the study and then the market link, the approach based on sources of tendency focuses more on capabilities of the organization or its core abilities, and therefore on the link of absorption capacity, and finally, the approach of knowledge-based participation, which believes that people can use their competence to create value: by transferring and converting knowledge internally and externally for the organization, which belongs to them, and consequently, the orientation of learning.

\subsection{The Definition of Concepts}

\subsubsection{Marketing Knowledge}

In organizational concepts, knowledge is composed of subcategories that are based on Porter's value chain. Including structural infrastructural knowledge, human resources knowledge, knowledge of logistics (inbound 
and outbound), administrative knowledge, marketing and sales knowledge, knowledge of development of technology and service knowledge, that marketing knowledge is the most important (Fu \& $\mathrm{Li}, 2005)$.

\subsubsection{Knowledge Sharing}

Means dissemination of knowledge and experiences across units of an organization. Knowledge sharing is very important in knowledge management because individual knowledge does not have a great effect in organizations unless it is available to others. Knowledge in organizations is an integrated and comprehensive subject. Knowledge sharing has many benefits, including rapid response to customers' demands, low-cost in operations, market orientation, innovation, financial performance and marketing (Hamidizadeh \& Azizi, 2009).

\subsubsection{Tendencies}

It is believed that individual and organizational tendencies for a certain behavior can be influenced by the person's purposes to perform a task like to share with the others knowledge and can have a greater impact on the actual performance of the individual (Hamidizadeh \& Azizi, 2009).

\section{Hypothesis}

Attitudes have a significant relationship with marketing knowledge sharing.

\section{Research Methodology}

This research is an applied research in its objective and in data collection method and nature of the data is the descriptive data correlative and like many similar descriptive studies, of the required data, library and documentary study, interview and questionnaire are used. The target population in this study is Iran's petrochemical industry that in the survey the sample is Arak petrochemical industry. The industry has been stratified based on its products considering costumers of each stratum. So the sample can represent of population that is Iran's petrochemical industry. In this study, the following equation is used to determine the sample size.

$$
n=\frac{z_{\frac{\alpha}{r}}^{r} \bar{p}(1-\bar{p})}{E^{r}}
$$

The sample size was estimated 90 people. Sampling method is the stratified random sampling. A standard questionnaire was used to collect data. Variable of marketing knowledge sharing includes three components (its worth for the individual and the organization, its culture in the organization and the executives supporting it) and 17 items (Moghimi \& Ramazan, 2011), and variable of attitudes consists of 5 components (method of knowledge sharing, accuracy and regularity, participants, duration and level of knowledge sharing) and 5 questions (Hamidizadeh, 2009). Logical validity (face and content) of questionnaires was reviewed and approved through several university professors and experts in this industry. Also construct validity was reviewed and approved by confirmatory factor analysis using AMOS software. Cronbach's alpha coefficient of over 0.7 was obtained for variables that indicated internal consistency of items and acceptable reliability of the questionnaire. Hypothesis test using univariate linear regression was performed with application of software spss.

\section{Research Findings}

\subsection{Normality Test of Distribution of Views for Variables}

In order to evaluate the normality of the research dimensions, Kolmogorov-Smirnov test was used. H0: Distribution of research variables is normal. H1: Distribution of research variables is not normal.

Table 2. Investigating normality of dimensions using the Kolmogorov-Smirnov test

\begin{tabular}{ccc}
\hline & Marketing knowledge sharing & Attitudes \\
\hline $\begin{array}{c}\text { Static value of } \\
\text { Kolmogorov-Smirnov }\end{array}$ & 1.01 & 1.21 \\
Significant level (p-value) & 0.25 & 0.11 \\
\hline
\end{tabular}

The results of Table 2 represent the normality of distribution of respondents' views. 


\subsection{Confirmatory Factor Analysis}

In this section, factor analysis of variables will be investigated and necessary modifications on the model are done.

5.2.1 The Results of Marketing Knowledge Sharing (MKS) before Modifying the Model

As you can see in Figure 4, the results of Marketing Knowledge Sharing (MKS) has been shown before modifying the model as well as the table of indicators of appropriateness of model for the latent variable of individual factors is displayed. Then it, we will display modified model and table of modified indicators.

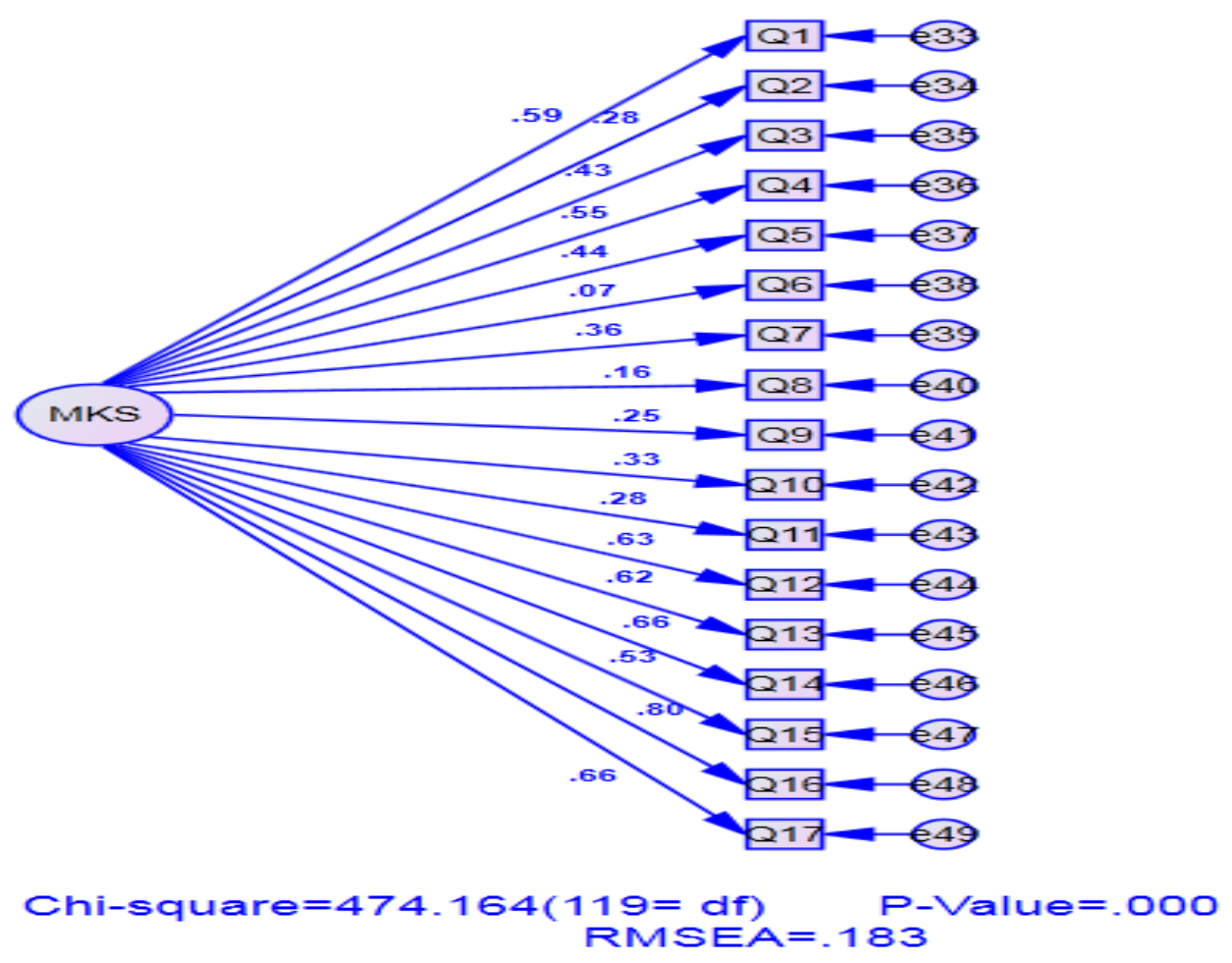

Figure 4. Results of Marketing Knowledge Sharing (MKS) before modifying the model

Table 3. Appropriate indices of model for latent variable of management of knowledge sharing before modifying the model

\begin{tabular}{ccc}
\hline Index & Calculated value & Appropriate value \\
\hline$\chi^{2}$ & 474.16 & --- \\
$d f$ & 119 & ---- \\
$\chi^{2} / d f$ & 3.98 & $\chi^{2} / d f<3$ \\
$R M S E A$ & 0.18 & $R M S E A<0.06$ \\
$C F I$ & 0.42 & $C F I>0.9$ \\
$I F I$ & 0.44 & $I F I>0.95$ \\
$G F I$ & 0.63 & $G F I>0.9$ \\
$A G F I$ & 0.52 & $A G F I>0.9$ \\
$N F I$ & 0.37 & $N F I>0.9$
\end{tabular}

The results of the indices of appropriateness of model for the latent variable of management knowledge sharing before modifying the model indicated the non-appropriateness of model, as it can be observed that RMSEA statistic value is more than 0.06 , also CFI index has been less than 0.9 . Also the ratio of chi-square statistic to 
degrees of freedom has been greater than 3. This non-appropriateness is also for other indices. So, the model was modified.

The results of Marketing Knowledge Sharing (MKS) after modifying model.

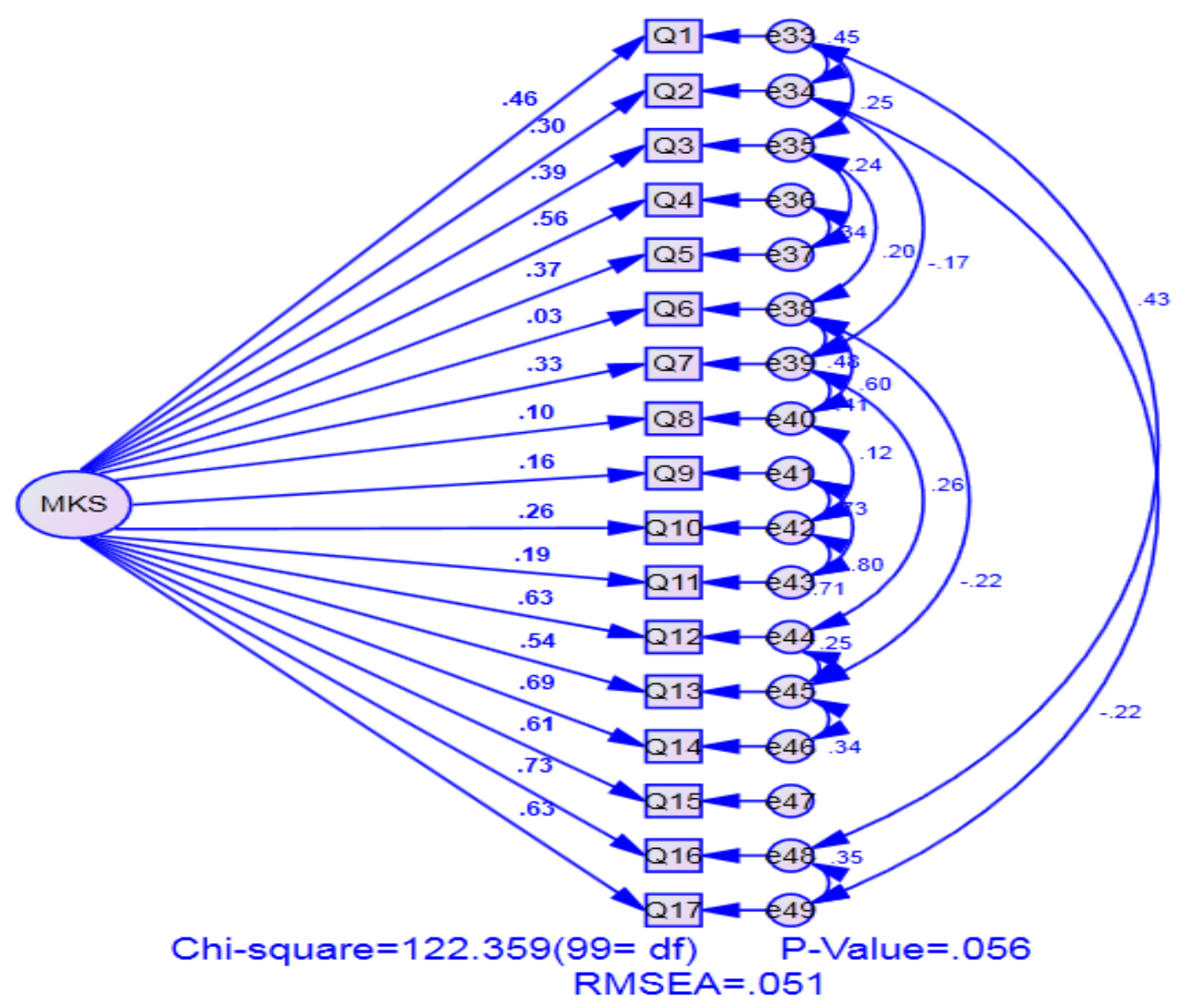

Figure 5. Results of Marketing Knowledge Sharing (MKS) before modifying the model

Table 4. Appropriate indices of model for latent variable of management of knowledge sharing after modifying the model

\begin{tabular}{ccc}
\hline Index & Calculated value & Appropriate value \\
\hline$\chi^{2}$ & 122.36 & --- \\
$d f$ & 99 & ---- \\
$\chi^{2} / d f$ & 1.24 & $\chi^{2} / d f<3$ \\
$R M S E A$ & 0.05 & $R M S E A<0.06$ \\
$C F I$ & 0.96 & $C F I>0.9$ \\
$I F I$ & 0.96 & $I F I>0.95$ \\
$G F I$ & 0.87 & $G F I>0.9$ \\
$A G F I$ & 0.8 & $A G F I>0.9$ \\
$N F I$ & 0.84 & $N F I>0.9$ \\
\hline
\end{tabular}

The results of the indices of appropriateness of model for the latent variable of marketing knowledge sharing after modifying the model indicated the appropriateness of model, as it can be observed that RMSEA statistic 
value is less than 0.06 , and CFI index has been more than 0.9 . Also the ratio of chi-square statistic to degrees of freedom has been less than 3 .

5.2.2 The Results of Attitude before Modifying the Model

As you can see in Figure 6, the results of attitude before modifying the model has been shown as well as the table of indicators of appropriateness of model for the latent variable of individual factors is displayed. Then, we will display modified model and table of modified indexes.

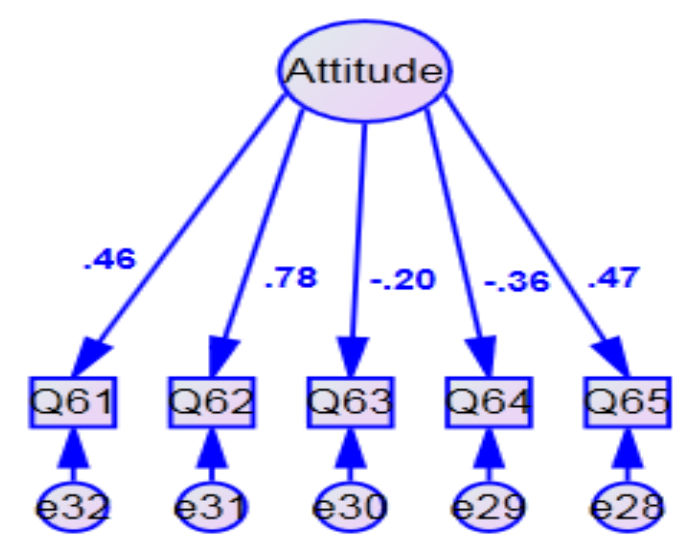

Chi-square $=12.195(5=\mathrm{df}) \quad \mathrm{P}-\mathrm{Value}=.032$

RMSEA $=.127$

Figure 6. Results of attitudes before modifying the model

Table 5. Appropriate indices of model for latent variable of attitude before modifying the model

\begin{tabular}{ccc}
\hline Index & Calculated value & Appropriate value \\
\hline$\chi^{2}$ & 12.19 & ---- \\
$d f$ & 5 & ---- \\
$\chi^{2} / d f$ & 2.44 & $\chi^{2} / d f<3$ \\
$R M S E A$ & 0.13 & $R M S E A<0.06$ \\
$C F I$ & 0.82 & $C F I>0.9$ \\
$I F I$ & 0.84 & $I F I>0.95$ \\
$G F I$ & 0.95 & $G F I>0.9$ \\
$A G F I$ & 0.84 & $A G F I>0.9$ \\
$N F I$ & 0.75 & $N F I>0.9$ \\
\hline
\end{tabular}

The results of the indices of appropriateness of model for the latent variable of attitudes before modifying the model indicated the non-appropriateness of model, as it can be observed that RMSEA statistic value is more than 0.06 , also CFI index has been less than 0.9. This non-appropriateness is also for other indices (except ratio of chi-square statistic to degrees of freedom). So, the model was modified. 


\subsubsection{The Results of the Attitudes after Modifying Model}

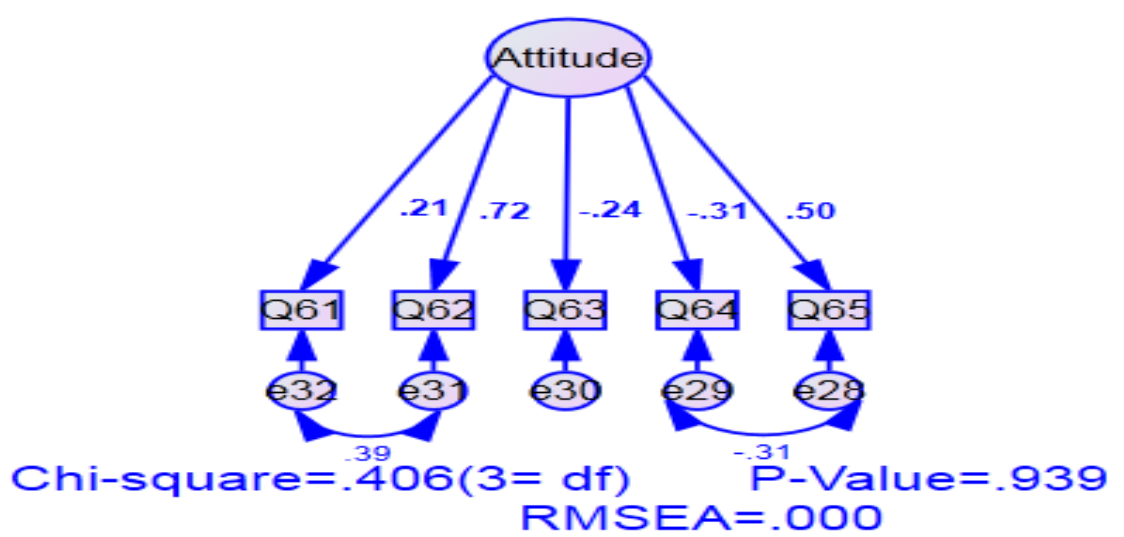

Figure 7. Results of attitudes after modifying the model

Table 6. Appropriate indices of model for latent variable of attitudes after modifying the model

\begin{tabular}{ccc}
\hline Index & Calculated value & Appropriate value \\
\hline$\chi^{2}$ & 0.41 & --- \\
$d f$ & 3 & ---- \\
$\chi^{2} / d f$ & 0.13 & $\chi^{2} / d f<3$ \\
$R M S E A$ & 0.00 & $R M S E A<0.06$ \\
$C F I$ & 1.00 & $C F I>0.9$ \\
$I F I$ & 1.00 & $I F I>0.95$ \\
$G F I$ & 0.99 & $G F I>0.9$ \\
$A G F I$ & 0.99 & $A G F I>0.9$ \\
$N F I$ & 0.99 & $N F I>0.9$
\end{tabular}

The results of the indices of appropriateness of model for the latent variable of attitudes after modifying the model indicated the appropriateness of model, as it can be observed that RMSEA statistic value is less than 0.06 , and CFI index has been more than 0.9. Also the ratio of chi-square statistic to degrees of freedom has been less than 3.

\subsection{Investigating the Position of Research Variables}

To compare the research dimensions with the value of their test, a single sample t-test was used that its results are shown in Table 6.

Table 7. Single-sample t-test to investigate the position of variables

\begin{tabular}{ccccccc}
\hline & \multicolumn{3}{c}{ Value of test=3 } & \multicolumn{2}{c}{ Confidence interval } \\
\cline { 2 - 7 } Variables & t value & $\begin{array}{c}\text { Degree of } \\
\text { freedom }\end{array}$ & p-value & $\begin{array}{c}\text { Difference of } \\
\text { mean }\end{array}$ & $\begin{array}{c}\text { Lower } \\
\text { bound }\end{array}$ & $\begin{array}{c}\text { Upper } \\
\text { bound }\end{array}$ \\
\hline Marketing knowledge sharing & $* 2.24$ & 89 & 0.027 & 0.12 & 0.01 & 0.23 \\
Attitude & $* * 2.78$ & 89 & 0.007 & 0.06 & 0.016 & 0.099 \\
\hline
\end{tabular}


The single sample t-test results showed that at the level of error of five percent, all aspects of the research with value of the test (ie 3 ) had significant difference so that their mean is higher than the value of the test.

\subsection{The Research Hypothesis}

Attitudes had a significant relationship with marketing knowledge sharing.

To evaluate the effect of attitudes variable on marketing knowledge sharing, first, the assumption of noncorrelation between the errors was investigated using Durbin-Watson test. With the results as follows:

Table 8. Results of Durbin-Watson test and appropriateness of model

\begin{tabular}{ccccc}
\hline $\begin{array}{c}\text { Coefficient of } \\
\text { determination }\end{array}$ & $\begin{array}{c}\text { Squared coefficient of de } \\
\text { termination }\end{array}$ & $\begin{array}{c}\text { Moderated coefficient } \\
\text { of determination }\end{array}$ & $\begin{array}{c}\text { Estimated } \\
\text { standard error }\end{array}$ & $\begin{array}{c}\text { Durbin-Watson } \\
\text { value }\end{array}$ \\
\hline 0.15 & 0.02 & 0.01 & 8.84 & 1.99 \\
\hline
\end{tabular}

Since Durbin-Watson value is between 1.5 and 2.5 therefore, the hypothesis of non-correlation between errors is not rejected. On one hand, normality of errors in Figure 1 also shows the normality. So, we can investigate the impact of attitudes on marketing knowledge sharing using univariate regression.

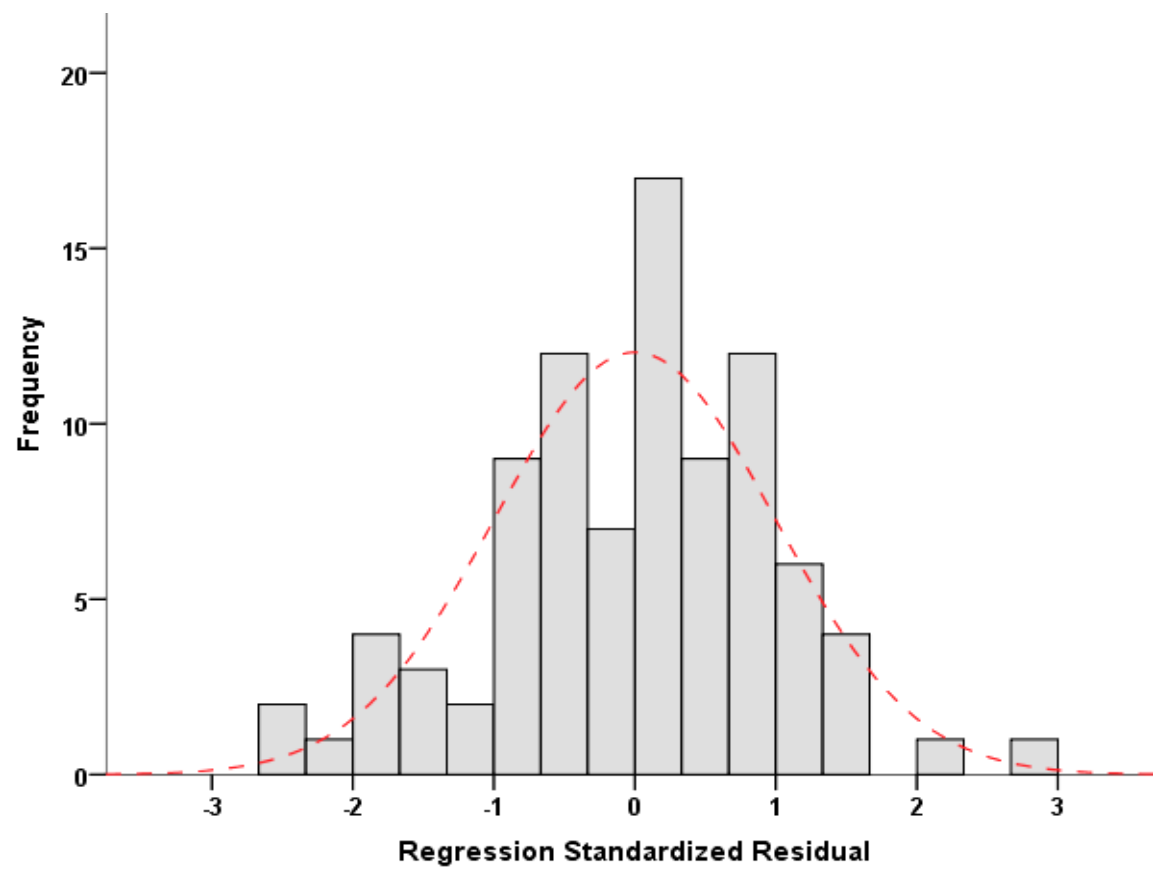

Figure 8 . Normality of errors of independent variable in the attitudes model and marketing knowledge sharing

Table 9. Impact of the attitudes variable on marketing knowledge sharing

\begin{tabular}{cccccccc}
\hline & $\begin{array}{c}\text { Non-standard } \\
\text { coefficient }\end{array}$ & $\begin{array}{c}\text { standard } \\
\text { coefficient }\end{array}$ & & & $\begin{array}{c}\text { Confidence interval of 95\% for } \\
\text { non-standard coefficients }\end{array}$ \\
\hline Variable & B & $\begin{array}{c}\text { Standard } \\
\text { error }\end{array}$ & Beta & t value & $\begin{array}{c}\text { Significant } \\
\text { level }\end{array}$ & Lower bound & Upper bound \\
Fix & 64.08 & 7.94 & $-----------~$ & $* * 8.07$ & $<0.001$ & 48.31 & 79.85 \\
Attitude & -1.32 & 0.95 & 0.15 & -2.39 & 0.17 & -3.21 & 0.56 \\
\hline
\end{tabular}


As you can see in table above, given that the $t$-statistic is less than $-1.96(t=-2.39)$, the relationship between these two variables has been significant at $5 \%$ error level (P-Value $<0.05$ ). So, the relationship between the marketing knowledge sharing and attitude is direct and negative. This means that people in the organization do not have a positive attitude and tendency toward knowledge sharing with others and the negative attitudes in relation to knowledge sharing has had more impact on employees. Standard regression coefficient (-0.15) also specifies the share of independent variable in explaining the changes of dependent variable so that for every one unit increase in the negative attitudes of people, knowledge sharing decreases 0.15 percent.

\section{Conclusion}

Here, a summary of the findings is presented:

The single sample t-test results showed that at the level of five percent error, all aspects had significant difference with the value of the test (ie 3) so that their mean has been more than the value of the test.

As the results showed, given that the $t$-statistic has been less than $-1.96(\mathrm{t}=-2.39)$, the relationship between attitudes and management knowledge sharing has been significant at the $5 \%$ error level (P-Value $<0.05)$. So, the relationship between marketing knowledge sharing and the attitudes is direct and negative. This means that people in the organization do not have a positive attitude and tendency toward knowledge sharing with others and negative attitudes in relation to knowledge sharing have had more impact on employees. Standard regression coefficient $(-0.15)$ also specifies the share of independent variable in explaining the changes of dependent variable that is to say for every one unit increase in negative attitude of people, knowledge sharing decrease 0.15 percent.

It is believed that individual tendencies for a certain behavior can be influenced by the intentions of the individual to accomplish a task such as knowledge sharing and can have a greater impact on the actual performance of the individual. The more positive the individuals attitudes in relation to knowledge sharing in the organization, becomes the more knowledge sharing occurs. These attitudes are created by a series of individual and organizational factors in the individuals, which are mentioned below. With the change of these factors the positive attitude could be created in relation to the knowledge sharing among employees.

\section{References}

Ajzen, I., \& Fishbein, M. (2000). Attitudes and the attitude-behavior relation: Reasoned and automatic processes.

Andriessen, J. H., \& Erik. (2006). To share or not to share, that is the question. In Conditions for the willingness to share knowledge. Delft Innovation System Papers.

Bandura, A. (1986). Social Foundations of Thought and Action. NJ: Prentice Hall.

Bock, G. W., \& Kim, Y. G. (2002). Breaking the myths of rewards. Information Resources Management Journal, 15(2), 14-21. https://dx.doi.org/10.4018/irmj.2002040102

Bock, G. W., \& Kim, Y. G. (2003). Exploring the influence of rewards on attitudes towards knowledge sharing. In M. Khosrow-Pour (Ed.), Advanced topics in information resources management. Hershey, PA, USA: Idea Group Publishing. https://dx.doi.org/10.4018/978-1-59140-062-2.ch011

Cabera, E. F., \& Cabera, A. (2005). Fostering Knowledge sharing through people management practice. International Journal of Human.

Cabrera, A., Collins, W. C., \& Salgado, J. F. (2006). Determinants of individual engagement in knowledge sharing.

Carter, C., \& Scarborough, H. (2001). Towards a second generation of knowledge management: The people

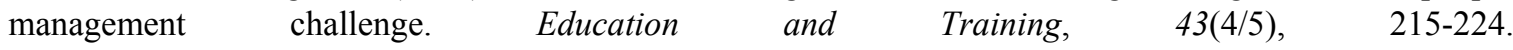
https://dx.doi.org/10.1108/EUM0000000005483

Chen, L. Y. (2006). Effect of Knowledge Sharing to Organizational Marketing Effectiveness in Lar ge Accounting Firms That Are Strategically.

Fu, S., \& Lee, M. (2005). IT-based knowledge sharing and organizational trust: The development and initial test of a comprehensive model. In Conference Proceedings. The European Conference On Information Systems.

Glazer, R. (1991). Marketing in an Information-Intensive Environment: Strategic Implications of Knowledge as an Asset. Joumal of Marketing, 55(4), 1-19. https://dx.doi.org/10.2307/1251953

Hamidizadeh, M. R., \& Azizi, S. (2009). Factors Affecting Marketing Knowledge Sharing (MKS): The Case of Iranian Food and Auto Industries. Indian Journal of Marketing, XXXIX(12), 40-49.

Hamidizadeh, M. R. (2010). Knowledge management and knowledge. Yaghut Publications, Qom. 
Kalman, M. E. (1999). The Effects of Organizational Commitment and Expected Outcomes on the Motivation to Share Discretionary Information in a Collaborative Database: Communication Dilemmas and Other Serious Games (Unpublished dissertation). University of Southern California.

Keshavarzi, A. H., Beiginia, A., \& Rezaei, Z. (2012). The role of interpersonal trust and knowledge sharing within the organization: The headquarters of the National Iranian Gas Company. Human Resource Management Research, 2(2).

Kharabsheh, R. A. (2007). A Model of Antecedents of Knowledge Sharing. The Electronic Journal of Knowledge Management, 5(4), 419-426.

Kwok, S. H., \& Gao, S. (2005). Attitude Toward Knowledge Sharing behavior. Journal of Computer Information Systems.

Li, L., \& Zhao, X. P. (2006). Enhancing Competitive Edge Through Knowledge Management in Implementing ERP Systems. Systems Research and Behavioral Science, 23(2), 129-140. https://dx.doi.org/10.1002/sres. 758

Liao, S. H., Chang, J. C., Cheng, S. C., \& Kuo, C. M. (2003). Employee relationship and knowledge sharing: A case study of a Taiwanese finance.

Lorenzon, A., Van Baalen, P. J., \& Pilotti, L. (2005). Marketing Knowledge Management in Strategic Adoption of a CRM.

Malhotra, Y., \& Galletta, D. F. (2003). Role of Commitment and Motivation in Knowledge Management Systems Implementation: Theory, Conceptualization, and Measurement of Antecedents of Success. In Proceedings of the 36th Hawaii International Conference on System Sciences (pp. 323-335). https://dx.doi.org/10.1109/hicss.2003.1174264

Moghimi, S. M., \& Ramazan, M. (2011). Journal of Management, 9.

Rossiter, J. (2001). What is Marketing Knowledge? Stage 1: Forms of Marketing Knowledge.

Soltani, S. (2013). Review of new product development and its relationship with competitive advantage (Master Thesis). University of Gilan.

Shalender, K., \& Agarwal, S. B. (1992). Resource Productivity and Factor Use Efficiency of Milk Production in Rural Areas of Mathura District (U.P). Indian Journal of Agricultural Economics, 47(3).

Shaw, M. J., Subramaniam, C., Tan, G. W., \& Welge, M. E. (2001). Knowledge Management and Data Mining for Marketing. Decision Support Systems, 31, 127-137. https://dx.doi.org/10.1016/S0167-9236(00)00123-8

Stajkovic, A. D., \& Luthans, F. (1998). Self-Efficacy and Work-Related Performance: A Meta-Analysis. Psychological Bulletin, 124, 240-261. https://dx.doi.org/10.1037/0033-2909.124.2.240

Su-Chao, C., \& Ming-Shing, L. (2008). The linkage between knowledge accumulation capability and organizational innovation. Journal of Knowledge Management, 12(1), 3-20. https://dx.doi.org/10.1108/13673270810852359

Tsai, M. T., \& Shih, C. M. (2004). Impact of marketing knowledge management among managers on marketing capabilities and business performance. International journal of management, 21(4), 524-530.

\section{Copyrights}

Copyright for this article is retained by the author(s), with first publication rights granted to the journal.

This is an open-access article distributed under the terms and conditions of the Creative Commons Attribution license (http://creativecommons.org/licenses/by/4.0/). 